\title{
MANAJEMEN PEMBELAJARAN PADA MADRASAH ALIYAH NEGERI (MAN) 1 MODEL BOJONEGORO JAWA TIMUR
}

\author{
Oleh : Hamam Burhanuddin ${ }^{1}$
}

\begin{abstract}
Abstrak
Manajemen pembelajaran adalah bagian pengelolaan terdepan yang mengembangkan kualitas setiap masukan pada aspek proses dan interaksi dalam sistem belajar mengajar. Oleh karena itu, perhatian yang sungguh-sungguh terhadap manajemen pembelajaran akan dapat mendorong peningkatan kualitas pendidikan. MAN 1 Bojonegoro merupakan salah satu lembaga pendidikan model yang tentunya menjadi unggulan apabila dibandingkan dengan madrasah lainnya di Bojonegoro. Untuk mengetahui informasi bagaimana penerapan manajemen pembelajaran di MAN 1 secara lebih mendalam. Berdasarkan pembahasan yang ada memberikan gambaran bahwa dalam pelaksanaan proses pembelajaran oleh guru di MAN 1 Bojonegoro pada dasarnya sudah melaksanakan prosedur manajemen pembelajaran yang meliputi perencanaan, pelaksanaan atau pengorganisasian, dan pengawasan. Semua guru membuat perencanaan dalam kegiatan pembelajaran yang akan dilaksanakan. Pada aspek pelaksanaan atau pengorganisasian pembelajaran secara umum diperoleh gambaran bahwa guru melaksanakan proses pengorganisasian pembelajaran dengan misi agar peserta didik membangun gagasan/pemahaman sendiri. Manajemen evaluasi secara umum telah melakukan kegiatan evaluasi dengan baik.
\end{abstract}

Kata Kunci: Manajemen, Pembelajaran, Madrasah Aliyah

\section{A. Pendahuluan}

Salah satu misi pendidikan di Indonesia adalah meningkatkan kualitas sumber daya manusia. Lulusan pendidikan yang

1 Dosen STIT Islamiyah Karya Pembangunan Paron Ngawi 


\section{8}

\section{JURNAL AL-AFKAR}

Vol. III, No. 2, Oktober 2015

berkualitas akan menjadi modal utama pembangunan nasional, terutama untuk perkembangan ekonomi. ${ }^{2}$ Semakin banyak orang yang berpendidikan, semakin mampu bagi suatu negara untuk membangun bangsanya. Dengan keterampilan, ilmu pengetahuan, agama, dan teknologi, Pemerintah lebih mudah dalam menggerakkan pembangunan nasional. Nilai yang kedua adalah investasi pendidikan untuk memberikan nilai balik yang lebih tinggi dalam investasi fisik di bidang lain. Nilai balik pendidikan adalah perbandingan antara total biaya yang dikeluarkan untuk membiayai pendidikan dengan total pendapatan yang akan diperoleh setelah seseorang lulus dan memasuki dunia kerja ${ }^{3}$. Menurut Suryadi (1999), negara-negara yang sedang berkembang umumnya menunjukkan nilai balik terhadap investasi pendidikan relatif lebih tinggi dalam investasi modal fisik, yaitu 20\% dibanding 15\%. Sementara itu, di negaranegara maju nilai balik investasi pendidikan lebih rendah apabila dibandingkan dengan investasi modal fisik, yaitu 9\% dibanding $13 \%{ }^{4}$

Salah satu langkah penting Pemerintah Indonesia dalam rangka meningkatkan kualitas lulusan pendidikan adalah menerapkan konsep Kurikulum Berbasis Kompetensi (KBK), yang kemudian berkembang lagi dengan penerapan Kurikulum Tingkat Satuan Pendidikan (KTSP) dan sekarang menjadi Kurikulum 2013 (K13). Hal ini dilatarbelakangi oleh hasil evaluasi Kementerian Pendidikan Nasional mengenai masih

2 Abdul Rahman, Shaleh, Madrasah dan Pendidikan Anak Bangsa: Visi, Misi dan Aksi. Rajawali Press, Jakarta. 2004. hlm. 123.

3 Dede Rosyada, Paradigma Pendidikan Demokratis: Sebuah Model Pelibatan Masyarakat dalam Penyelenggaraan Pendidikan. Kencana, Jakarta, 2004., hlm. 25-26.

4 Suryadi, Ace Pendidikan, Investasi SDM dan Pembangunan: Isu, Teori dan Aplikasi, Balai Pustaka, Jakarta. 1999. hlm. 247. 
Hamam Burhanuddin

rendahnya kualitas lulusan peserta didik sekolah menengah, khususnya kesiapan lulusan sekolah menengah dalam memasuki dunia kerja ${ }^{5}$. Sementara itu, pelaksanaan kurikulum yang ada bersamaan pula dengan kebijakan otonomi daerah, yang tentunya akan memberikan peran manajemen sekolah semakin besar pula.

Manajemen sekolah mencakup pengembangan manajemen pembelajar-an. Sesungguhnya, sebesar apa pun masukan persekolahan ditambah atau diperbaiki, lulusannya tetap tidak akan optimal, apabila faktor manajemen pembelajaran yang merupakan aspek yang sangat strategis dalam proses belajar mengajar tidak diberi perhatian. Manajemen pembelajaran adalah bagian pengelolaan terdepan yang mengembangkan kualitas setiap masukan pada aspek proses dan interaksi dalam sistem belajar mengajar. Di sini guru memiliki peran yang besar untuk mendorong atau menghambat upaya inovasi baik yang berasal dari luar maupun yang timbul dari dalam pembelajaran di sekolahnya ${ }^{6}$. Guru harus mampu memutuskan apa yang harus diajarkan, bagaimana menyajikan bahan pelajaran, dan bagaimana menentukan cara pengajaran agar peserta didik mengerti apa yang diajarkan dan mampu menerapkan dalam kehidupan nyata. ${ }^{7}$ sehingga dalam hal ini kemampuan manajemen pembelajaran seorang guru sangat penting dan menentukan untuk mencapai keberhasilan belajar.

5 Dimyati dan Mudjiono, Belajar dan Pembelajaran. Rineka Cipta, Jakarta. Fattah, Nanang 1999. Landasan Manajemen Pendidikan. Remaja Rosdakarya, Bandung 2006. hlm. 286-288.

6 Oemar Hamalik, Manajemen Pengembangan Kurikulum. Remaja Rosdakarya, Bandung. 2006, hlm. 150. Lihat juga Muhaimin, Pengembangan Kurikulum Pendidikan Agama Islam di Sekolah, Madrasah dan Perguruan Tinggi. Rajawali Press, Jakarta. 2005. hlm. vii.

7 Brophy, Jere E Educational Psychology. Longman, New York. 1990. hlm. 32. 


\section{JURNAL AL-AFKAR \\ Vol. III, No. 2, Oktober 2015}

Dalam kenyataan sehari-hari, di dalam suatu ruang kelas ketika proses Kegiatan Belajar-Mengajar (KBM) berlangsung, kadang-kadang sebagian besar peserta didik belum mampu mengikuti proses pembelajaran secara maksimal sewaktu guru mengajar. Sebagian peserta didik belum mampu mencapai kompetensi individual yang diperlukan untuk mengikuti peserta didik lanjutan. Juga, beberapa peserta didik belum belajar sampai pada tingkat pemahaman. Kadang-kadang peserta didik baru mampu mempelajari (baca: menghafal) fakta, konsep, prinsip, hukum, teori, dan gagasan inovatif lainnya pada tingkat ingatan. Mereka belum dapat menggunakan dan menerapkannya secara efektif dalam pemecahan masalah sehari-hari yang dialami. Salah satu penyebabnya adalah guru yang belum mampu mengelola manajemen pembelajaran di kelas secara optimal. ${ }^{8}$ Kalau masalah ini dibiarkan dan berlanjut terus, lulusan sebagai generasi penerus bangsa akan sulit bersaing dengan lulusan dari negara-negara lain. Lulusan yang diperlukan tidak sekedar mampu mengingat dan memahami informasi, tetapi juga mampu menerapkan secara kontekstual melalui beragam kompetensi. Di era pembangunan yang berbasis ekonomi dan globalisasi sekarang ini diperlukan pengetahuan dan keanekaragaman keterampilan agar peserta didik mampu memberdayakan dirinya untuk menemukan, menafsirkan, menilai, dan menggunakan informasi, serta melahirkan gagasan kreatif untuk menentukan sikap dalam pengambilan keputusan.

Salah satu dampak dari kurang berkualitasnya proses pembelajaran di kelas di antaranya adalah keluhan masyarakat yang dapat dipantau melalui berbagai media massa mengenai

8 Oemar Hamalik, Op Cit, hlm. 17. 
Hamam Burhanuddin

mutu pendidikan dan prestasi belajar peserta didik. Mutu pendidikan akan selalu menarik perhatian masyarakat Indonesia karena masa depan bangsa tergantung kepada pendidikan, terutama pada saat memasuki era globalisasi. Mutu pendidikan pada umumnya dan prestasi belajar peserta didik di sekolah pada khususnya merupakan hasil suatu proses interaksi berbagai faktor seperti: guru, peserta didik, kurikulum, buku, laboratorium, metodologi pengajaran, peraturan perundang-undangan di bidang pendidikan, dan berbagai masukan serta kondisi proses lainnya.

Faktor-faktor yang menjadi masukan seperti disebutkan di atas telah ditangani selama ini, baik kualitas maupun kuantitasnya. Oleh karena itu, kondisi saat ini sudah lebih baik daripada kondisi sebelumnya, tetapi mutu pendidikan dan prestasi belajar peserta didik seperti yang diinginkan belum terwujud. Tampaknya ada suatu faktor yang selama ini belum mendapatkan perhatian yang setara dengan perhatian yang diberikan kepada faktor-faktor lainnya, yaitu manajemen pembelajaran. Sudah cukup banyak dana yang dialokasikan untuk mengangkat dan menatar guru dan tidak sedikit rupiah yang telah dihabiskan untuk mencetak buku, membeli peralatan laboratorium, mengadakan sarana dan prasarana pendidikan, tetapi masih sangat sedikit upaya yang dilakukan untuk meningkatkan efisiensi dan efektivitas manajemen pendidikan secara umum, termasuk di dalamnya manajemen pembelajaran.

Berdasarkan uraian di atas, jelaslah bahwa manajemen pembelajaran merupakan faktor penting untuk menentukan keberhasilan proses pendidikan yang berlangsung di sekolah. 


\section{JURNAL AL-AFKAR \\ Vol. III, No. 2, Okiober 2015}

Oleh karena itu, perhatian yang sungguh-sungguh terhadap manajemen pembelajaran akan dapat mendorong peningkatan kualitas pendidikan. Ini tidak terbatas hanya pada lembaga pendidikan umum, tetapi juga pada lembaga pendidikan keagamaan, seperti madrasah. Untuk madrasah ini, sebagaimana diketahui, bahwa Madrasah Aliyah Negeri 3 Palembang merupakan salah satu lembaga pendidikan model yang tentunya menjadi unggulan apabila dibandingkan dengan madrasah lainnya di Bojonegoro Selatan, (surat keputusan Menteri Agama RI No. E.IV/PP.00.6/17.A/1998/tertanggal 20 Februari 1998). Meski dirancang sebagai Madrasah Aliyah model, kondisi manajemen pembelajaran di MAN 1, "belum sepenuhnya dikatakan lebih baik dan menjadi model bagi madrasah Aliyah lainnya di Bojonegoro " (Wawancara dengan Fajar, 2 Februari 2015). Berdasarkan kondisi ini patut diduga bahwa masih dibutuhkan upaya peningkatan kualitas pembelajaran di MAN 1 , terutama pada aspek manajemen pembelajaran yang lebih optimal. Untuk mengetahui informasi bagaimana penerapan manajemen pembelajaran di MAN 1 secara lebih mendalam, penulis tertarik untuk mengkaji permasalahan ini lebih lanjut.

Berdasarkan latar belakang masalah yang telah dipaparkan di atas, dapat diajukan pokok permasalahan yaitu bahwa Madrasah Aliyah Negeri 3 Bojonegoro merupakan lembaga pendidikan model yang dirancang menjadi Madrasah Aliyah Unggulan di Bojonegoro. Oleh karena itu, perlu dikaji bagaimana penerapan manajemen pembelajaran yang telah dilaksanakan oleh lembaga pendidikan itu agar dapat menjadi model bagi madrasah Aliyah lain. 


\section{B. Pembahasan}

1. Hakikat Manajemen Pembelajaran

Keterampilan manajemen merupakan hal yang penting dalam pembelajaran yang baik. Manajemen yang baik yang dilaksanakan oleh guru akan menghasilkan perkembangan keterampilan manajemen diri peserta didik yang baik. Ketika peserta didik telah belajar untuk lebih mangatur diri, guru akan lebih mudah untuk berkonsentrasi pada pembelajaran yang efektif.

Teknik manajemen pembelajaran harus diupayakan agar tidak mengganggu aspek pembelajaran. Tindakan manajemen harus mencegah agar tidak terjadi masalah. Faktor-faktor yang perlu diperhatikan dalam pemilihan strategi manajemen yang tepat adalah (1) tingkat kematangan peserta didik dan hubungannya dengan orang lain, (2) jumlah peserta didik, jumlah dan jenis alat, ruang, keterbatasan waktu, dan tujuan pembelajaran, dan (3) kepribadian guru9 ${ }^{9}$ Tugas guru yang kritis dalam meningkatkan prestasi belajar peserta didik adalah bagaimana merancang dan mengimplementasikan teknik pembelajaran agar banyaknya waktu belajar aktif peserta didik tinggi, dan agar peluang belajar mencukupi serta dan iklim kelas kondusif.

Pengajaran pada umumnya adalah kegiatan kelompok, sedangkan pembelajaran lebih kepada kegiatan individu dan tidak semua peserta didik belajar dengan kecepatan yang sama atau dengan cara yang sama. Guru perlu mempertimbangkan berapa banyak kebijakan dan praktek yang mengarah kepada pengelompokan peserta didik. Penelitian tentang interaksi guru dan peserta didik menunjukkan bagaimana guru sering

9 Oemar Hamalik, Ibid, hlm. 131. 


\section{JURNAL AL-AFKAR \\ Vol. III, No. 2, Oktober 2015}

berperilaku berbeda kepada individu peserta didik berdasarkan pada persepsi mereka sendiri tentang kemampuan peserta didik. ${ }^{10}$ Peserta didik yang diberi label "berprestasi rendah" atau "peserta didik lamban belajar" sering menerima sedikit kesempatan apabila di bandingkan dengan orang lain untuk berpartisipasi, dan mereka yang dipandang sebagai "tak berdisiplin" diperlakukan sedemikian rupa, bahkan ketika mereka berperilaku baik. Guru perlu mengarahkan pada asumsi dan ekspektasi mereka dengan meminta umpan balik dari peserta didik tentang proses belajarmengajar dan tentang apa yang terjadi di kelas pada umumnya. Semua guru harus melakukan yang terbaik bagi peserta didik dengan cara mengenali mereka sebagai individu dengan cara positif, memperlakukan mereka dengan adil dan dengan hormat, membuat pelajaran menarik dan beragam, memberikan dorongan dan mengatakan agar mereka meyakini diri mereka sendiri dan kemampuannya.

\section{Fungsi-Fungsi Manajemen Pembelajaran}

Manajemen merupakan kegiatan, pelaksanaannya disebut manajing, dan orang yang melakukannya disebut manajer. Tugastugas operasional dilaksanakan melalui upaya-upaya karyawan/ staf. Manajemen mempunyai tujuan-tujuan tertentu dan bersifat tidak berwujud (Terry, 2006, hlm. 9). ${ }^{11}$ Manajemen dikatakan tidak berwujud karena tujuan manajemen tidak dapat dilihat, tetapi dapat dirasakan hasilnya berupa hasil pekerjaan yang cukup, ada kepuasan pribadi, produk, dan pelayanan yang

${ }^{10}$ Nasution, MN, Manajemen Mutu Terpadu (Total Quality Management). Ghalia Indonesia, Jakarta. 2001. hlm. 71.

${ }^{11}$ George R, Terry, Prinsip-Prinsip Manajemen. Terjemahan J. Smith D. F. M. Bumi Aksara, Jakarta. 2006, hlm. 9. 
Hamam Burhanuddin

optimal. Untuk mencapai tujuan-tujuan usaha suatu kelompok organisasi membutuhkan manajemen agar dapat dicapai dengan baik. Dengan demikian, dapat dipahami bahwa manajemen mempunyai fungsi-fungsi tertentu sehingga mampu secara positif mewujudkan pencapaian tujuan organisasi.

Menurut Terry (2006), secara fundamental manajemen mempunyai fungsi perencanaan, organisasi, gerakan aksi, motivasi, penempatan, pengarahan, kontrol dan inovasi atau pengembangan. Secara spesifik fungsi manajemen dapat dijelaskan; pertama, fungsi perencanaan, menetapkan pekerjaan yang harus dilaksanakan oleh kelompok untuk mencapai tujuan. Kedua, organisasi, pembagian peranan kerja yang memungkinkan anggota bekerjasama secara efektif guna mencapai tujuan bersama. Ketiga, gerakan aksi, kegiatan yang ditetapkan oleh unsur perencanaan dan pengorganisasian agar tujuan-tujuan dapat tercapai. Keempat, motivasi, dorongan yang timbul baik dari dalam diri seseorang maupun dari orang lain sehingga mau melakukan atau tidak melakukan sesuatu. Kelima, menempatkan atau mempertahankan orang pada posisi yang dibutuhkan oleh pekerjaan atau organisasi. Keenam, pengarahan, penugasan atau masukan-masukan yang diberikan kepada bawahan sehingga menjadi aktif dan efektif dalam bekerja. Ketujuh, kontrol, mencakup kelanjutan tugas untuk melihat apakah kegiatan-kegiatan dilaksanakan sesuai rencana. Pelaksanaan tugas dievaluasi oleh pimpinan (manajer), dan penyimpanganpenyimpangan yang tidak diinginkan diperbaiki supaya tujuantujuan dapat tercapai dengan baik. Kedelapan, inovasi atau pengembangan, yang mencakup pengembangan gagasan-gagasan baru, memadukan pemikiran-pemikiran baru dengan yang 


\section{JURNAL AL-AFKAR \\ Vol. III, No. 2, Oktober 2015}

lama, mencari gagasan-gagasan dengan memadukannya dengan berbagai kondisi yang ada dan menerapkannya.

Perencanaan adalah tindakan awal untuk melaksanakan pembelajaran. Melalui perencanaan akan menentukan tujuan dan menetapkan metode yang tepat untuk mencapai tujuan pembelajaran. Menurut Uno (1998), perencanaan pembelajaran pada hakikatnya adalah perancangan upaya untuk membelajarkan peserta didik. Pembelajaran memusatkan perhatian pada "bagaimana membelajarkan peserta didik", dan bukan pada "apa yang dipelajari peserta didik". Perencanaan pembelajaran secara umum diperlukan agar perbaikan pembelajaran dapat dicapai.

Berdasarkan pengertian di atas, perencanaan pembelajaran dapat dipahami sebagai upaya guru dalam menyiapkan desain pembelajaran yang berisi tujuan, materi dan bahan, alat dan media, pendekatan, metode serta evaluasi yang akan dijadikan pedoman dalam pembelajaran. Perencanaan pembelajaran sangat penting karena menjadi pedoman dan standar dalam usaha pencapaian tujuan. Pembelajaran menjadi terarah dan terukur karena adanya perencanaan yang matang.

Pengorganisasian pembelajaran adalah proses pembagian komponen-komponen pembelajaran sehingga dapat dikerjakan atau dilaksanakan dengan baik. ${ }^{12}$ Untuk mengorganisasikan suatu kegiatan pembelajaran dibutuhkan strategi, yang menurut Reigeluth (1977) sebagaimana dikutip oleh Uno (2006), yang mengacu kepada strategi pengorganisasian pembelajaran untuk membuat urutan, mensintesis fakta, konsep, prosedur, dan prinsip yang berkaitan. Membuat urutan mengacu pada

${ }^{12}$ Syafaruddin dan Irwan Nasution Manajemen Pembelajaran. Quantum Teaching, Jakarta, 2005. Hlm. 72. 
pembuatan urutan penyajian isi mata pelajaran. Sintesis mengacu pada upaya menunjukkan kepada peserta didik mengenai fakta, konsep, prosedur atau prinsip yang terkandung dalam suatu mata pelajaran. Senada dengan pengertian di atas, Sanjaya (2006) menyatakan bahwa pengorganisasian sebagai kegiatan menyusun struktur dan membentuk hubunganhubungan agar diperoleh kesesuaian dalam usaha mencapai tujuan bersama. Pengorganisasian akan memberi makna kepada adanya unsur-unsur yang mempersatukan dan memisahkan dengan tujuan, keselarasan, dan keseimbangan. Unsur-unsur yang mempersatukan di antaranya adalah tujuan bersama untuk diwujudkan, sedangkan unsur-unsur yang memisahkan adalah kewenangan membagi-bagikan tugas dan tanggungg jawab. Tujuan bersama dalam pembelajaran adalah guru dan peserta didik bersama-sama berusaha mencapai tujuan pembelajaran. Unsur-unsur dalam pembelajaran yang memisahkan adalah kewenangan guru dalam menyampaikan materi pembelajaran dan kewajiban peserta didik untuk mematuhi dan menerima apa yang disampaikan oleh guru. Dengan demikian, pengorganisasian pembelajaran memberi gambaran bahwa kegiatan belajar dan mengajar mempunyai arah dan tanggung jawab yang jelas. Fungsi dan tanggung jawab yang ada pada masing-masing unsur berangkat dari kebersamaan untuk memenuhi tujuan pembelajaran.

Kepemimpinan dalam pembelajaran merupakan salah satu faktor yang menentukan keberhasilan guru dalam mengelola kegiatan pembelajaran. Mondy dan Premeaux (1995), yang dikutip oleh Syafaruddin dan Nasution (2006), mengatakan bahwa kepemimpinan berkaitan dengan kemampuan yang dimiliki seseorang dalam mempengaruhi orang lain. Kepemimpinan 


\section{JURNAL AL-AFKAR \\ Vol. III, No. 2, Oktober 2015}

intinya adalah hubungan antar manusia. Kepemimpinan guru dalam pembelajaran ini mencakup setidaknya empat gaya kepemimpinan (Syafaruddin dan Nasution, 2006, hlm. 74), yaitu:

1. Pemimpin otokratik, yakni pemimpin yang otoriter terhadap bawahannya tanpa boleh bertanya atau protes terhadap apa yang ditugaskan;

2. Pemimpin partisipatif, yakni pemimpin yang selalu melibatkan bawahannya dalam merumuskan kebijakan atau keputusan, tetapi otoritas akhir sering terdapat pada pimpinan;

3. Pemimpin demokratis, yakni pemimpin yang selalu bermusyawarah dengan bawahannya mengenai apa yang akan diputuskan;

4. Pemimpin yang selalu membebaskan bawahan, yakni pemimpin yang tidak perduli terhadap apa yang dilakukan bawahannya asal tidak mengganggu stabilitas organisasi.

Dari keempat gaya kepemimpinan itu semuanya dapat dilakukan oleh guru dalam kegiatan pembelajaran, tetapi perlu diperhatikan segi positifnya mana yang lebih banyak ataupun bila perlu melalui penggabungan gaya kepemimpinan di atas. Berkenaan dengan kepemimpinan pembelajaran ini, Sagala (2005, hlm. 145) mengatakan bahwa peran guru sebagai motivator para peserta didik melakukan aktivitas belajar baik di kelas, laboratorium, perpustakaan, praktek kerja lapangan, dan tempat lainnya yang memungkinkan peserta didik melakukan kegiatan belajar. Oleh karena itu, guru bukan saja berusaha menarik perhatian peserta didik, tetapi juga harus meningkatkan aktivitas 
Hamam Burhanuddin

peserta didik melalui pendekatan dan metode pembelajaran yang sesuai dengan materi pembelajaran yang disajikan oleh guru.

Pengawasan dan evaluasi merupakan bagian dari manajemen pembelajaran yang berfungsi sebagai kontrol terhadap semua aktivitas yang dilaksanakan dalam upaya memastikan keberhasilan pembelajaran. Dalam hal pengawasan dan evaluasi ini, yang lebih menonjol adalah pada tataran evaluasinya, yang menurut Dimyati dan Mudjiono (2006), merupakan evaluasi mencakup evaluasi hasil belajar dan evaluasi pembelajaran. Evaluasi hasil belajar menekankan pada diperolehnya informasi tentang seberapakah perolehan peserta didik dalam mencapai tujuan pembelajaran. Evaluasi pembelajaran merupakan proses sistematis untuk memperoleh informasi tentang keefektifan proses pembelajaran dalam membantu peserta didik mencapai tujuan pembelajaran secara optimal. ${ }^{13}$

\section{Penerapan Manajemen Pembelajaran}

a) Perencanaan Pembelajaran

Perencanaan merupakan proses penyusunan sesuatu yang akan dilaksanakan untuk mencapai tujuan yang telah ditentukan. Pelaksanaan perencanaan itu dapat disusun berdasarkan kebutuhan dalam jangka waktu tertentu sesuai dengan keinginan pembuat perencanaan. Namun, yang lebih utama adalah perencanaan yang dibuat harus dapat dilaksanakan dengan mudah dan tepat sasaran. Begitu pula dengan perencanaan pembelajaran yang direncanakan harus sesuai dengan target pendidikan. Guru sebagai subjek dalam membuat perencanan dituntut

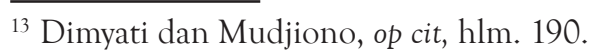


dapat menyusun berbagai program pembelajaran sesuai dengan pendekatan dan metode yang akan digunakan. Dalam konteks desentralisasi pendidikan -wewenang pengelolaan pendidikan ada pada pemerintah daerah- dan seiring dengan perwujudan pemerataan hasil pendidikan yang bermutu, diperlukan standar kompetensi mata pelajaran yang dapat dipertanggungjawabkan dalam hubungan dengan lokal, nasional, dan global. Standar kompetensi bahan kajian itu harus dikuasai peserta didik di seluruh Indonesia. Dengan demikian, melalui standar kompetensi yang berdiversifikasi, keanekaragaman kemampuan daerah dapat dilayani dengan berpijak pada kompetensi umum lulusan (Kurikulum Berbasis Kompetensi, 2003, hlm. 1).

Untuk menggali informasi tentang aplikasi manajemen pembelajaran di MAN 1 Bojonegoro, penulis menentukan 6 responden untuk diwawancarai dengan perincian guru mata pelajaran Pendidikan Agama Islam (PAI) sebanyak 1 orang, guru mata pelajaran yang diujikan secara nasional sebanyak 4 orang (Matematika, Bahasa Indonesia, Bahasa Inggris, dan Ekonomi), dan guru mata pelajaran umum sebanyak 1 orang (Wawancara dengan Syamsul Arifin, Sri Rohmin, Desi Saliana, Muslim, Sri Wahyuni, dan Marwansyah, 17 Juli 2015). Dari jawaban 6 responden terhadap pertanyaan apakah guru membuat perencanaan dalam kegiatan pembelajaran yang akan dilaksanakan, diperoleh hasil tentang perencanaan pembelajaran di MAN 1 Bojonegoro dapat diuraikan bahwa: Pertama, Semua responden menjawab "ya" dalam membuat perencanaan dalam kegiatan pembelajaran yang akan dilaksanakan. Ini menunjukkan bahwa pada dasarnya guru MAN 1 Bojonegoro telah melakukan prosedur pembelajaran dengan menyusun rencana apabila 
akan melaksanakan kegiatan pembelajaran. Kedua, bentuk perencanaan yang dipersiapkan atau disusun oleh guru adalah; membuat silabus, program tahunan, program semester, Rancangan Pelaksanaan Pembelajaran (RPP), kartu soal, kartu jawaban, dan daftar penilaian. Semua responden memberikan jawaban yang sama bahwa mereka melaksanakan semua bentuk perencanaan pembelajaran sebagaimana disebutkan di atas.

Secara umum bentuk perencanaan yang telah dilakukan oleh guru MAN 1 Bojonegoro telah memenuhi ketentuan pedoman kegiatan pembelajaran yang berlaku di Indonesia. Namun dari informasi wawancara dengan responden tentang aspek perencanaan itu, diperoleh jawaban bahwa perencanaan yang belum terpenuhi adalah alat penilaian terhadap moral dan budi pekerti. Di sini guru kesulitan dalam cara melakukan penilaian terhadap moral dan budi pekerti peserta didik. Untuk menyikapi ini, salah seorang responden mengatakan: "Budi pekerti peserta didik semakin berkurang, tetapi guru kesulitan untuk memberikan penilaian bila dihubungkan dengan pelajaran yang diberikan. Untuk itu, solusinya sebaiknya moral dan budi pekerti ini diberikan sebagai mata pelajaran" (wawancara dengan Marwansyah, 17 Juli 2015).

Mengenai tanggapan guru terhadap pertanyaan apakah perencanaan pembelajaran yang telah disiapkan sudah sesuai dengan ketentuan yang diatur dalam pedoman kegiatan pembelajaran, diperoleh tanggapan responden tentang kesesuaian perencanaan pembelajaran dengan pedoman yang ada diperoleh gambaran jawaban yang bervariasi. 1 orang responden menjawab sangat sesuai, 2 orang menjawab sesuai dan 3 orang menjawab belum sepenuhnya sesuai. Alasan masing-masing 
responden, yang menjawab sesuai karena memang dianggap telah memenuhi semua ketentuan dalam pedoman perencanaan pembelajaran yang ditetapkan oleh pihak madrasah (wawancara dengan Syamsul Arifin, 17 Juli 2015). Responden yang menjawab sesuai didasarkan pada telah dipenuhinya ketentuan yang telah ditetapkan oleh pihak Madrasah (wawancara dengan Muslim dan Desi Saliana, 17 Juli 2007). Responden yang memberikan tanggapan bahwa perencanaan pembelajaran yang dilaksanakan belum sepenuhnya sesuai didasarkan pada belum terpenuhinya alat penilaian dan media pembelajaran yang belum memadai atau belum tersedia di MAN 1 Bojonegoro.

Berdasarkan kekurangan itu perencanaan pembelajaran yang dibuat menjadi tidak bisa memenuhi pedoman perencanaan pembelajaran yang ada. Mengenai media pembelajaran itu menurut beberapa responden yang diwawancarai menjawab bahwa media pembelajaran sangat dibutuhkan dalam kegiatan pembelajaran namun fasilitas tersebut belum memadai. Hal itu terutama berkaitan dengan pelajaran bahasa Inggris, IPA dan Pendidikan Agama Islam (Wawancara dengan Desi Saliana, Muslim dan Marwansyah, 17 Juli 2007). Media pembelajaran yang belum terpenuhi antara lain; laboratorium IPA, laboratorium Bahasa Inggris, dan CD hadits dan al Qur'an digital.

Tanggapan responden terhadap perhatian dan upaya Kepala Madrasah meningkatkan kemampuan perencanaan pembelajaran bagi guru. Informasi yang diperoleh bahwa seluruh responden memberikan jawaban, kepala Madrasah mendukung dan sangat memperhatikan aspek perencanaan pembelajaran. Ini dibuktikan dengan setiap bulan dilakukan pemeriksaan 
berkas pembelajaran guru dalam mengajar, termasuk di dalamnya mengenai SAP dan hal-hal yang berkenaan dengan perencanaan pembelajaran di MAN 1 Bojonegoro. Selain itu Kepala Madrasah sering memberikan masukan dan pengarahan mengenai bagaimana menyusun perencanaan pembelajaran yang baik, terutama tentang Rancangan Perencanaan Pembelajaran (RPP), penyusunan program semester, penyusunan Satuan Acara Pembelajaran (SAP), memberikan contoh SAP yang dianggap baik dan perlu dijadikan acuan (Wawancara dengan Syamsul Arifin, Sri Rohmin, Desi Saliana, Muslim, Sri Wahyuni, dan Marwansyah, 17 Juli 2015).

\section{Pengorganisasian Pembelajaran}

Salah satu ciri pembelajaran yang berkualitas adalah proses pembelajaran yang mempesona, menarik, mengasyikkan, menyenangkan, tidak membosankan, variatif, kreatif, dan indah. Dalam proses pembelajaran di Madrasah Aliyah diperlukan proses pembelajaran demikian itu sebab pada umumnya anakanak remaja mempunyai perhatian yang berbeda-beda, bosan belajar dan berlatih, menentukan kegiatannya sesuai dengan ditentukan oleh suasana hati dan menyenangi hal-hal yang indah, menggembirakan, dan memberikan daya tantangan. Pendidik dituntut piawai dalam hal menciptakan proses pembelajaran yang mempesona dan membesut metode serta sarana yang mampu membuat mereka asyik belajar, melakukan sesuatu dengan variasi yang memadai. Pendidik harus kreatif dan inovatif dalam menciptakan alat dan sarana belajar, tidak kekurangan akal dan sarana untuk mengaktifkan peserta didik dalam proses pembelajaran. 


\section{JURNAL AL-AFKAR \\ Vol. III, No. 2, Oktober 2015}

Hasil penggalian data di MAN 1 Bojonegoro tentang bentuk kegiatan yang dilakukan dalam pengorganisasian pembelajaran yakni; dari beberapa jawaban responden yang diberi pertanyaan tentang kegiatan dalam pengorganisasian pembelajaran diperoleh tanggapan bahwa semua tes awal dilakukan oleh guru, yang dilanjutkan dengan ceramah. Praktek dalam pembelajaran ternyata hanya dilakukan oleh guru tertentu saja, yakni guru mata pelajaran Bahasa Inggris. Pengucapan dalam Bahasa Inggris kadangkala dilakukan dalam percakapan. Guru mata pelajaran Matematika mempraktekkan rumus-rumus Matematika. Guru mata pelajaran Bahasa Indonesia mempraktekkan mengarang dan menulis essai. Guru mata pelajaran Agama terutama mempraktekkan pelajaran sholat dan doa (wawancara dengan Sri Rohmin, Marwansyah, Muslim, dan Sri Wahyuni, 17 Juli 2015).

Tes menulis, membaca dan diskusi, serta tes akhir semuanya dilakukan oleh guru. Ini ternyata dari semua responden yang memberikan tanggapan bahwa mereka melakukannya. Namun, dalam hal tes mendengarkan hanya dilakukan oleh guru mata pelajaran Bahasa Inggris (Wawancara dengan Syamsul Arifin, Sri Rohmin, Desi Saliana, Muslim, Sri Wahyuni, dan Marwansyah, 17 Juli 2015).

Secara umum ditemukan gambaran mengenai proses pengorganisasian pembelajaran yang dilaksanakan oleh guru di MAN 1 Bojonegoro sebagai berikut:

1. Salam pembuka diberikan untuk membulatkan perhatian peserta didik terhadap mata pelajaran yang akan disampaikan. Salam pembuka ini adalah ucapan "Assalamu'alaikum warakhmatullahi wabarakatuh". Kemudian pembelajaran dilanjutkan dengan ucapan 
Hamam Burhanuddin

pujian kepada Allah Swt dan shalawat kepada Nabi Muhammad Saw.

2. Tes awal, dilakukan untuk mengukur kemampuan peserta didik dalam bahan pelajaran yang akan disampaikan.

3. Pengorganisasian pembelajaran dilakukan dengan beberapa strategi. Pertama, guru menjelaskan tujuan belajar kepada peserta didik. Pada permulaan belajar mengajar terlebih dahulu seorang guru menjelaskan mengenai tujuan pembelajaran yang akan dicapai kepada peserta didik. Hal itu dilakukan karena pada prinsipnya makin jelas tujuan, maka makin besar pula motivasi dalam belajar. Kedua, guru memberikan hadiah -berupa pujian dan kata-kata yang mampu menggugah semangat dan motivasi- untuk peserta didik yang berprestasi. Hal ini dianggap akan memacu semangat mereka untuk bisa belajar lebih giat lagi. Di samping itu, peserta didik yang belum berprestasi akan termotivasi agar dapat mengejar kedudukan peserta didik lainnya yang berprestasi.

Dalam hal kepemimpinan dalam pembelajaran, diperoleh informasi jawaban responden yang bahwa kepemimpinan dalam pembelajaran guru MAN 1 Bojonegoro dalam pengorganisasian pembelajaran mempunyai beberapa variasi. Namun yang paling banyak dipakai adalah jenis kepemimpinan demokratis. Melalui jenis kepemimpinan ini, menurut salah satu responden dimunculkan" sikap sportifdalam diripesertadidikdalam berbagai kegiatan ketika berhadapan dengan orang lain" (Wawancara dengan Syamsul Arifin, 4 Juli 2015). Tipe kepemimpinan partisipatif dipergunakan ketika ada kelompok peserta didik yang dianggap berbuat positif -melakukan perbuatan yang itu 
dapat menjadi contoh yang baik bagi peserta didik yang lainsehingga guru perlu memberikan motivasi dengan berpartisipasi mengikuti kegiatan yang dilakukan, seperti; diskusi, debat dan tanya jawab. Jenis kepemimpinan yang membebaskan diterapkan sewaktu-waktu, terutama ketika peserta didik dianggap mampu mengatur diri sendiri dalam berkreativitas, seperti; menyusun rencana kegiatan. Jenis kepemimpinan otokratis dapat pula diterapkan apabila guru menghadapi peserta didik yang dianggap melanggar disiplin dan sulit diatur.

Secara umum diperoleh gambaran bahwa dalam hubungan dengan pengorganisasian pembelajaran, guru MAN 1 Bojonegoro beranggapan bahwa belajar merupakan proses peserta didik membangungagasan/pemahamansendiri. Kegiatan pembelajaran dituntut dapat memberikan kesempatan seluas-luasnya kepada peserta didik untuk berbuat, berpikir, berinteraksi sendiri secara lancar dan termotivasi tanpa hambatan oleh guru. Suasana belajar yang disediakan guru diharapkan dapat memberikan peluang kepada peserta didik untuk melibatkan mental secara aktif melalui beragam kegiatan, seperti kegiatan mengamati, bertanya/ mempertanyakan, menjelaskan, berkomentar, mengajukan hipotesis, mengumpulkan data, dan sejumlah kegiatan mental lainnya seperti berdiskusi dan berdialog. Guru tidak memberikan bantuan secara dini dan hendaknya selalu menghargai usaha peserta didik meskipun hasilnya belum sempurna. Selain itu, guru mendorong peserta didik supaya berbuat/berpikir dengan lebih baik, misalnya melalui pengajuan pertanyaan menantang yang 'menggelitik' sikap ingin tahu dan sikap kreativitas peserta didik. Guru juga harus mampu memberikan penguatan, yakni pemberian tanggapan dalam proses interaksi belajar mengajar 
Hamam Burhanuddin

baik berupa pujian maupun sanksi. Pemberian penguatan ini dimaksudkan untuk lebih meningkatkan keaktifan belajar dan mencegah berulangnya kesalahan peserta didik. Penguatan yang sifatnya positif itu sering dilakukan dengan kata-kata: bagus! baik!, betul!, hebat! Semua itu tidak disajikan dengan cara berpura-pura, tetapi harus tulus dari hati nurani guru. Penguatan lainnya dapat dilakukan dengan gerak; acungan jempol, tepuk tangan, menepuk-nepuk bahu, menjabat tangan.

Beberapa strategi dan metode pengajaran perlu memprioritaskan situasi nyata. Kalau guru sulit menyediakan situasi nyata, baru menyediakan alternatif di bawahnya, seperti situasi buatan, atau alat audio visual, atau alat visual, dan cara dengan pola audio (metode ceramah di kelas baru dipilih oleh guru MAN 1 Bojonegoro setelah cara-cara itu tidak mungkin disediakan) (Wawancara dengan Syamsul Arifin, Sri Rohmin, Desi Saliana, Muslim, Sri Wahyuni, dan Marwansyah, 17 Juli 2015).

Tanggapan semua responden tentang peran Kepala Madrasah dalam kaitannya dengan aspek pengorganisasian pembelajaran adalah selalu memberikan dukungan fasilitas selagi mampu dipenuhi oleh pihak Madrasah. Di samping itu, Kepala Madrasah juga selalu memberikan arahan mengenai pentingnya pengorganisasian pembelajaran karena arahan ini dianggap mempunyai peranan yang dominan untuk keberhasilan pendidikan di MAN 1 Bojonegoro. Meskipun demikian, keluhan yang diajukan oleh para responden terhadap pengorganisasian pembelajaran adalah masih belum adanya media yang mampu memenuhi semua kegiatan pembelajaran secara optimal. Kelemahan ini, misalnya belum adanya fasilitas in focus dan 


\section{8}

\section{JURNAL AL-AFKAR}

Vol. III, No. 2, Oktober 2015

komputer yang dapat dipakai sebagai media pembelajaran yang dapat membantu proses pembelajaran lebih efisien, dan kurangnya sarana penerangan di ruang-ruang kelas ketika terjadi hujan dan mendung, ruangan kelas sering gelap karena kekurangan cahaya matahari (Wawancara dengan Syamsul Arifin, Sri Rohmin, Desi Saliana, Muslim, Sri Wahyuni, dan Marwansyah, 17 Juli 2015).

\section{Pengawasan/Evaluasi Pembelajaran}

Dalam sistem persekolahan terdapat dua jenis pengendalian, yaitu supervisi dan evaluasi. Supervisi merupakan pembinaan yang dilakukan oleh Kepala Madrasah dan Wakil Kepala Madrasah. Kegiatan evaluasi hasil belajar merupakan salah satu pengawasan keberhasilan pembelajaran yang fokusnya adalah peserta didik. Salah satu pengawasan yang berkaitan dengan kegiatan pembelajaran dilakukan dengan melaksanakan tes kemajuan belajar peserta didik. Dalam sistem pendidikan di Indonesia umumnya, termasuk juga madrasah, jenis-jenis tes kemajuan belajar mencakup tes akhir yang berupa ujian semester atau ujian nasional dan tes sumatif, yakni tes pada waktu selesai belajar. Kegiatan evaluasi hasil belajar merupakan salah satu pengawasan keberhasilan pembelajaran. Untuk menentukan nilai rapor, guru MAN 1 Bojonegoro umumnya menggunakan nilai tes akhir semester. Menurut tanggapan responden, langkah-langkah evaluasi dalam kegiatan pembelajaran adalah melaksanakan evaluasi pada setiap kegiatan pembelajaran sebagai berikut: pertama, guru mempersiapkan kartu soal yang digunakan sebagai alat evaluasi pelaksanaan pembelajaran. Kedua, guru melakukan penilaian awal kepada peserta didik tentang aspek-aspek penting tentang bahan pelajaran yang akan disampaikan. Bila peserta 
Hamam Burhanuddin

didik telah mengetahui tujuan dari pembelajaran yang sedang mereka ikuti, maka mereka akan terdorong untuk melaksanakan kegiatan tersebut secara aktif. Oleh karena itu pada setiap awal kegiatan guru MAN 1 Bojonegoro dituntut memberi penjelasan kepada peserta didik tentang apa dan untuk apa materi pelajaran itu harus mereka pelajari serta apa keuntungan yang akan mereka peroleh. Selain itu, guru mengadakan kesepakatan bersama dengan para peserta didiknya mengenai tata tertib belajar yang berlaku agar kegiatan pembelajaran dapat berlangsung lebih efektif. Melalui tes awal juga dapat diketahui tingkatan pengetahuan peserta didik terhadap bahan pelajaran yang akan diterimanya, yang dilanjutkan dengan kegiatan pembelajaran. Menurut salah satu responden, "guna penilaian awal adalah untuk membuat peserta didik termotivasi untuk mengetahui lebih dalam tentang bahan pelajaran yang akan disampaikan. Motivasi peserta didik bertambah besar karena didorong rasa ingin tahu karena dipancing oleh guru dengan pertanyaan-pertanyaan. Oleh karena itu, penilaian awal mestinya diberikan dan dikemas dengan bahasa yang membuat peserta didik termotivasi untuk mendalaminya" (Wawancara dengan Muslim, 5 Juli 2015). Ketiga, setelah kegiatan pembelajaran berlangsung, evaluasi dilakukan pada akhir pembelajaran. Evaluasi ini dimaksudkan untuk mengetahui pemahaman peserta didik mengenai bahan pembelajaran yang telah disampaikan. Responden menyatakan bahwa penilaian akhir dilakukan dengan menggunakan kartu soal yang sudah disiapkan pada tahap perencanaan pembelajaran. Kartu soal dibuat sesuai dengan bahan pelajaran yang disampaikan atau, dengan kata lain, kartu soal berisi bagian-bagian penting bahan pembelajaran yang akan ditanyakan kepada peserta didik 
(Wawancara dengan Syamsul Arifin, Sri Rohmin, Desi Saliana, Muslim, Sri Wahyuni, dan Marwansyah, 17 Juli 2015).

Manajemen evaluasi ini juga mencakup tes yang dilakukan di jam pelajaran di kelas. Hal itu dilakukan oleh guru MAN 1 Bojonegoro terutama pada pelaksanaan pertengahan semester atau ujian tengah semester dan ujian semester. Kegiatan evaluasi lainnya adalah pelaksanaan ujian nasional bagi peserta didik yang duduk di kelas tiga. Temuan yang diperoleh menunjukkan bahwa ujian tengah semester dijadwalkan oleh pihak Madrasah secara khusus sehingga guru dapat melakukannya sesuai dengan jadwal yang telah ditetapkan. Apa yang diujikan itu berkenaan dengan bahan pembelajaran yang sudah diajarkan sebelumnya. Ujian semester juga dilakukan secara terjadwal pada akhir semester.

Pada aspek manajemen evaluasi secara umum guru MAN 1 Bojonegoro telah melakukan kegiatan evaluasi dengan baik, yang dibuktikan dengan secara teratur dan terjadwal melakukan kegiatan evaluasi, baik evaluasi pada setiap kegiatan pembelajaran maupun pada saat tengah semester dan akhir semester. Kelemahan yang ditemukan dalam hal ini adalah adanya kesulitan guru untuk melakukan evaluasi pembelajaran harian atau setiap pertemuan, baik penilaian pada awal pembelajaran maupun penilaian pada akhir pembelajaran. Guru sering menemukan kesulitan untuk memberikan pertanyaan yang dapat membuat peserta didik menjadi tertarik dan termotivasi untuk mengikuti kegiatan pembelajaran yang akan dilaksanakan. Namun menurut salah seorang responden (Wawancara dengan Desi Saliana, 5 Juli 2015), "kesulitan itu sebenarnya dapat diatasi oleh guru yang mempunyai wawasan pengetahuan yang luas sehingga mampu membahasakannya secara lebih menarik dan mengugah motivasi 
Hamam Burhanuddin

peserta didik". Dengan demikian dapat dipahami bahwa guru harus terus membaca dan menggali ilmu pengetahuan terutama yang berkaitan dengan mata pelajaran yang diajarkannya. Dinamisasi ilmu pengetahuan guru akan berpengaruh pula terhadap perkembangan ilmu pengetahuan yang akan diperoleh peserta didik.

6. Upaya Guru dalam Meningkatkan Kemampuan Manajemen Pembelajaran

a) Perencanaan Pembelajaran

Dalam perencanaan pembelajaran yang dilaksanakan oleh guru di MAN 1 Bojonegoro diperoleh gambaran bahwa dari 6 responden yang diberi pertanyaan tentang upaya yang dilakukan dalam meningkatkan kemampuan perencanaan pembelajaran diperoleh jawaban sebanyak 5 item. Alasan responden memilih jawaban bahwa urutan pertama upaya peningkatan kemampuan perencanaan pembelajaran adalah melalui membaca literatur di perpustakaan karena cara tersebut merupakan termudah dilakukan. Jawaban kedua adalah dengan bertanya kepada rekan sejawat karena itu sering dilakukan selama ini oleh guru-guru MAN 1 Bojonegoro. Mengikuti pelatihan, seminar dan penataran juga merupakan sumber informasi yang dapat meningkatkan kemampuan perencanaan pembelajaran bagi guru, namun dari kesemua responden yang menjawab mengikuti seminar dan sejenisnya hanya 4 orang, 2 orang responden lainnya tidak menjadikan seminar dan sejenisnya sebagai upaya peningkatan kemampuan manajemen perencanaan pembelajaran. Ini didasarkan atas pengalaman 2 responden yang mengatakan bahwa mereka tidak pernah mengikuti kegiatan seminar atau 
sejenisnya yang berkaitan dengan peningkatan kemampuan manajemen perencanaan pembelajaran. Alasannya adalah terbatasnya peserta yang diikutkan dalam pelatihan (wawancara dengan Marwansyah dan Desi Saliana, 17 Juli 2015). Membuka internet dan berdiskusi dengan rekan sejawat merupakan urutan terakhir jawaban responden, yang menggambarkan bahwa tidak banyak guru di MAN 1 sudah mengenal internet sebagai sarana peningkatan wawasan ilmu pengetahuan. Responden yang menjadikan internet sebagai sarana untuk meningkatkan kemampuan perencanaan pembelajaran berjumlah 2 orang; sisanya mengaku tidak mempunyai akses untuk membuka internet. Adapun diskusi dengan teman sejawat dilakukan oleh semua responden dalam meningkatkan kemampuan perencanaan pembelajaran guru (Wawancara dengan Syamsul Arifin, Sri Rohmin, Desi Saliana, Muslim, Sri Wahyuni, dan Marwansyah, 17 Juli 2015).

\section{b) Pengorganisasian Pembelajaran}

Berkenaan dengan upaya guru dalam peningkatan kemampuan pelaksanaan pembelajaran di MAN 1 Bojonegoro bahwa dari semua jawaban responden diperoleh gambaran berdasarkan urutan pilihan jawaban bahwa upaya guru dalam meningkatkan kemampuan pelaksanaan pembelajaran yang paling dominan adalah melalui membaca literatur yang berkaitan dengan materi pembelajaran yang akan disampaikan. Disamping itu, upaya yang dilakukan adalah dengan mempelajari silabus yang akan diajarkan. Alasan yang diajukan oleh guru mengapa mempelajari silabus karena memang silabus menjadi acuan dalam pelaksanaan pembelajaran. Membaca dan memahami silabus akan mampu mengarahkan guru untuk selalu melaksanakan 
Hamam Burhanuddin

pembelajaran secara sistematis dan terarah. Jawaban lain dalam upaya peningkatan kemampuan pelaksanaan pembelajaran adalah mengikuti pelatihan, seminar, dan penataran, meskipun hal itu tidak secara rutin. Mengenai hal ini hanya 4 responden yang memberikan tanggapan bahwa mereka mengikuti seminar, pelatihan, atau sejenisnya dianggap sebagai sarana untuk meningkatkan kemampuan guru dalam pengorganisasian pembelajaran. Sisanya, 2 responden, menganggap seminar dan sejenisnya tidak berpengaruh terhadap peningkatan kemampuan guru dalam pengorganisasian pembelajaran. Alasan responden yang menjawab demikian adalah bahwa mereka jarang mempunyai kesempatan mengikuti pelatihan, dan seminar, yang berkaitan dengan masalah pengorganisasian pembelajaran. Menurut informasi responden, apabila ada kegiatan pelatihan, seminar, atau penataran, maka guru MAN 1 Bojonegoro semuanya menjawab bahwa mereka sangat ingin untuk ikut guna mencari wawasan baru melalui pelatihan, seminar atau penataran. Namun, kesempatan itu sangat terbatas sehingga terkadang dalam setahun ada guru tidak memperoleh kesempatan mengikuti seminar atau pelatihan (Wawancara dengan Syamsul Arifin, Sri Rohmin, Desi Saliana, Muslim, Sri Wahyuni, dan Marwansyah, 17 Juli 2015).

Membuka internet juga menjadi jawaban responden dalam rangka meningkatkan kemampuan pelaksanaan pembelajaran. Hanya 2 responden saja yang menganggap bahwa internet merupakan sebagai salah satu sumber informasi guna meningkatkan kemampuan pengorganisasian pembelajaran dan sebagai sarana peningkatan kemampuan pengorganisasian pembelajaran guru. Ini didorong oleh masih rendahnya kemampuan guru MAN 1 Bojonegoro dalam memanfaatkan 


\section{4}

\section{JURNAL AL-AFKAR}

Vol. III, No. 2, Oktober 2015

internet dalam kehidupan sehari-hari. Melalui internet, menurut 2 orang responden, guru dapat membaca artikel-artikel yang ada di berbagai situs berkenaan dengan informasi pelaksanaan pembelajaran (wawancara dengan Marwansyah dan Desi Saliana, 17 Juli 2015).

\section{c) Evaluasi Pembelajaran}

Menurut pendapat para responden, evaluasi atau penilaian pada dasarnya bertujuan untuk mengetahui perkembangan hasil belajar peserta didik dan hasil mengajar guru. Informasi hasil belajar atau hasil mengajar merupakan kompetensi dasar yang dikuasai dan yang belum dikuasasi oleh peserta didik. Hasil belajar digunakan untuk memotivasi peserta didik dan untuk perbaikan serta peningkatan kualitas pembelajaran oleh guru. Pemanfaatan hasil belajar untuk memperbaiki dan meningkatkan kualitas pembelajaran harus didukung oleh peserta didik, guru, Kepala Madrasah, dan orang tua peserta didik. Dukungan ini akan diperoleh apabila mereka memperoleh informasi hasil belajar yang lengkap dan akurat. Untuk itu, diperlukan laporan perkembangan hasil belajar peserta didik untuk guru atau sekolah, untuk peserta didik, dan untuk orang tua (Wawancara dengan Syamsul Arifin, Sri Rohmin, Desi Saliana, Muslim, Sri Wahyuni, dan Marwansyah, 17 Juli 2015).

Dalam pelaksanaan evaluasi secara umum, guru-guru MAN 1 Bojonegoro berpedoman kepada ketentuan Madrasah dan peraturan pemerintah, yang salah satunya adalah dengan mengarahkan peserta didik untuk berhasil dalam mengikuti evaluasi tingkat nasional atau Ujian Nasional bagi peserta didik kelas 3. Secara umum responden memberikan tiga jawaban tentang upaya yang dilakukan guru MAN 1 Bojonegoro dalam 
Hamam Burhanuddin

rangka meningkatkan kemampuan pelaksanaan evaluasi. Pertama, guru membaca literatur, yang itu berkenaan dengan materi pelajaran yang disampaikan. Kedua, guru mempelajari soal-soal yang telah diujikan pada UN, karena soal-soal yang diujikan dalam UN sebelumnya tidak menutup kemungkinan akan keluar lagi pada UN yang akan datang, yang biasanya dengan beberapa perubahan. Kemampuan guru dalam melaksanakan evaluasi sangat mempengaruhi penentuan keberhasilan peserta didik dalam kegiatan pembelajaran. Oleh karena itu, berbagai upaya dilakukan oleh guru MAN 1 Bojonegoro agar evaluasi yang dilaksanakan memang betul-betul mencerminkan tingkat keberhasilan pembelajaran yang telah dilakukan. Untuk itu, salah satu cara yang diterapkan di MAN 1 Bojonegoro adalah dengan menyusun bank soal. Bank soal ini menjadi sumber guru dalam memberikan ujian atau evaluasi kepada peserta didik. Adanya bank soal memudahkan pula tugas Kepala Madrasah mengawasi keberhasilan pembelajaran suatu mata pelajaran karena soal-soal yang ada pada bank soal merupakan cerminan pembelajaran yang ada. Apabila evaluasi yang dilaksanakan guru menggunakan sumber dari bank soal dan peserta didiknya berhasil menjawab dengan benar, maka hal itu menunjukkan keberhasilan peserta didik dalam penguasaan bahan pelajaran yang disampaikan (Wawancara dengan Syamsul Arifin, Sri Rohmin, Desi Saliana, Muslim, Sri Wahyuni, dan Marwansyah, 17 Juli 2015).

Selain membaca literatur dan mempelajari soa-soal yang sudah diujikan secara nasional, terdapat 4 responden yang menjawab bahwa membaca ulang bahan pembelajaran yang sudah disampaikan merupakan salah satu sarana penting untuk meningkatkan kemampuan evaluasi. Ini berdasarkan alasan 


\section{JURNAL AL-AFKAR}

Vol. III, No. 2, Oktober 2015

bahwa dengan membaca ulang tentang bahan pembelajaran yang sudah disampaikan merupakan sarana mengingat kembali bahan pembelajaran yang sudah disampaikan dan memberikan inspirasi untuk dikembangkan dalam merumuskan kemampuan evaluasi kepada peserta didik (Wawancara dengan Syamsul Arifin, Desi Saliana, Sri Wahyuni, dan Marwansyah, 17 Juli 2015).

Dari segi hasil, guru dikatakan berhasil jika pembelajaran mampu mengubah perilaku sebagian besar peserta didik. Agar guru dapat mengimplementasikan kurikulum secara efektif, guru harus memiliki hal-hal berikut: (1) menguasai dan memahami bahan pelajaran dan hubungannya dengan bahan pelajaran lain dengan baik; (2) menyukai apa yang diajarkan dan menyukai mengajar sebagai suatu profesi; (3) memahami peserta didik, pengalaman, kemampuan, dan prestasinya; (4) menggunakan metode bervariasi; (5) mampu mengeliminasi bahan pelajaran; (6) mengikuti perkembangan pengetahuan dan teknologi; (7) merencanakan proses pembelajaran; (8) memotivasi peserta didik memperoleh hasil belajar lebih baik; dan (9) menghubungkan pengalaman yang lalu dengan bahan yang akan diajarkan. Guru perlu memahami, semua peserta didik dilahirkan dengan rasa ingin tahu yang tak pernah terpuaskan. Mereka memiliki potensi untuk memenuhi rasa ingin tahunya. Oleh Karena itu, tugas utama guru adalah bagaimana mengembangkan lingkungan belajar yang menyenangkan agar dapat membangkitkan rasa ingin tahu peserta didik, sehingga tumbuh minat dan semangat untuk terus belajar

Keberhasilan pembelajaran juga sangat ditentukan oleh Kepala Madrasah dalam mengatur, menggerakkan, dan menyelaraskan semua sumber daya pendidikan. Kepemimpinannya sebagai 
Hamam Burhanuddin

faktor pendorong untuk mewujudkan visi, misi, tujuan, termasuk sasaran. Oleh karena itu, ia dituntut memiliki kemampuan manajemen dan kepemimpinan yang tangguh. Kepala Madrasah harus mampu memobilisasi sumber daya madrasah, perencanaan dan evaluasi program, kurikulum, pembelajaran, pengelolaan personalia, sarana dan sumber belajar, keuangan, pelayanan peserta didik, hubungan dengan masyarakat, dan penciptaan iklim kondusif. Dengan demikian dipahami bahwa Kepala Madrasah mempunyai tugas yang cukup kompleks dalam membina meningkatkan kualitas pembelajaran di lembaga yang ia pimpin.

\section{Penutup}

Berdasarkan uraian di atas maka simpulan yang dapat dirumuskan bahwa; dalam pelaksanaan proses pembelajaran, guru di MAN 1 Bojonegoro pada dasarnya sudah melaksanakan prosedur manajemen pembelajaran yang meliputi perencanaan, pelaksanaan atau pengorganisasian, dan pengawasan. Semua guru membuat perencanaan dalam kegiatan pembelajaran yang akan dilaksanakan. Ini menunjukkan bahwa pada dasarnya guru MAN 1 Bojonegoro telah melakukan prosedur pembelajaran dengan menyusun rencana apabila akan melaksanakan kegiatan pembelajaran. Bentuk perencanaan yang dipersiapkan atau disusun oleh guru adalah: membuat silabus, membuat program tahunan, membuat program semester, membuat Rancangan Pelaksanaan Pembelajaran (RPP), membuat kartu soal, dan membuat kartu jawaban serta membuat daftar penilaian. Dari semua perencanaan itu diperoleh gambaran bahwa guru 


\section{8}

\section{JURNAL AL-AFKAR}

Vol. III, No. 2, Oktober 2015

mengalami kesulitan dalam menyusun alat penilaian moral dan budi pekerti.

Pada aspek pelaksanaan atau pengorganisasian pembelajaran, secara umum diperoleh gambaran bahwa guru MAN 1 Bojonegoro melaksanakan proses pengorganisasian pembelajaran dengan misi agar peserta didik membangun gagasan/pemahaman sendiri. Oleh karena itu, guru memberikan kesempatan seluas-luasnya kepada peserta didik untuk berbuat, berpikir, dan berinteraksi sendiri secara lancar dan termotivasi tanpa hambatan oleh guru. Untuk mewujudkan hal itu, maka kepemimpinan guru lebih dominan menggunakan kepemimpinan demokratis. Pada aspek manajemen evaluasi, secara umum guru MAN 1 Bojonegoro telah melakukan kegiatan evaluasi dengan baik, yang dibuktikan dengan secara teratur dan terjadwal melakukan kegiatan evaluasi, baik evaluasi pada setiap kegiatan pembelajaran maupun pada saat tengah semester dan akhir semester. Akan tetapi, kelemahan yang ditemukan pada aspek ini adalah adanya kesulitan guru untuk melakukan evaluasi pembelajaran harian atau setiap pertemuan, baik penilaian pada awal pembelajaran maupun penilaian pada akhir pembelajaran.

Upaya guru MAN 1 Bojonegoro dalam meningkatkan kemampuan manajemen pembelajaran adalah, antara lain, bahwa pada aspek manajemen perencanaan, upaya guru dilakukan melalui membaca berbagai sumber bacaan (literatur) di perpustakaan, bertanya kepada rekan sejawat, mengikuti pelatihan, seminar dan penataran, membuka internet, dan berdiskusi dengan rekan sejawat. Pada aspek pelaksanaan atau pengorganisasian pembelajaran, upaya yang dilakukan oleh guru adalah membaca berbagai sumber bacaan (literatur) yang 
berkaitan dengan bahan pembelajaran, mempelajari silabus yang akan diajarkan, mengikuti pelatihan, seminar, dan penataran, serta membuka internet. Pada aspek manajemen evaluasi, upaya yang dilakukan oleh guru adalah membaca berbagai sumber bacaan (literatur), mempelajari soal-soal yang telah diujikan dalam Ujian Nasional (UN), dan membaca ulang bahan pembelajaran yang sudah disampaikan.

Berdasarkan apa yang dikemukakan di atas dapat diperoleh gambaran bahwa MAN 1 Bojonegoro yang Model atau percontohan bagi madrasah-madrasah aliyah lain yang ada di Propinsi Bojonegoro Selatan pada aspek fasilitas memang lebih lengkap dengan sarana Pusat Sumber Belajar Bersama (PSBB) serta laboratorium IPA dan fasilitas lainnya. Namun pada aspek manajemen pembelajaran masih sama dengan Madrasah Aliyah lainnya di Bojonegoro Selatan. Dengan kata lain, manajemen pembelajaran MAN 1 Bojonegoro belum dapat dijadikan sebagai model manajemen pembelajaran bagi madrasah aliyah lainnya. 
Vol. III, No. 2, Oktober 2015

\section{DAFTAR PUSTAKA}

Abrasyi, M. Athiyah 1993. Dasar-Dasar Pokok Pendidikan Islam. Terjemahan H. Bustami A. Gani dan Djphar Bahry, Bulan Bintang, Jakarta

Andriani, Durri 1999. Manajemen Sistem Pendidikan Terbuka dan Jarak Jauh. SEAMOLEC-PUSTEKKOM, Jakarta

Arnold, Hugh J and Daniel C Feldman 1986. Organizational Behavior. McGraw-Hill Book Company, New York

Atmodiwirio, Soebagio 2005. Manajemen Pendidikan Indonesia. Ardadizya Jaya, Jakarta.

Baron, Robert A1989. Psychology. Allyn and Bacon, Boston.

Bloom, Benyamin S 1981. Taxonomy of Educational Objectives. Longman, London

Brophy, Jere E 1990. Educational Psychology. Longman, New York. Budiningsih, C. Asri 2005. Belajar dan Pembelajaran. Rineka Cipta, Jakarta.

Cecco, John P 1968. The Psychology of Learning and Instruction: Educational Psychology. Prentice-Hall International, Inc. London.

Davis, Ivor. K 1991. Pengelolaan Belajar. Terj. Rajawali Press, Jakarta.

Dimyati dan Mudjiono 2006. Belajar dan Pembelajaran. Rineka Cipta, Jakarta.

Fattah, Nanang 1999. Landasan Manajemen Pendidikan. Remaja Rosdakarya, Bandung. 
Fauzan, Mohammad 2005. "Kontribusi Efektivitas Manajemen terhadap Kinerja Guru (Studi Tentang Perencanaan, Pelaksanaan dan Pengawasan terhadap Kinerja Guru Madrasah Aliyah Negeri (MAN) di Kabupaten Bandung Tahun 2004-2005)”, tesis Universitas Pendidikan Indonesia Bandung. Tidak diterbitkan.

Gagne, Robert M dan Marcy Perkins Driscoll 1988. Essentials of Learning forInstruction. Prentice Hall, New Jersey.

Gage, N.L. dan David C. Berliner 1988. Educational Psychology. Houghton Miffin Company, Boston.

Hadiyanto 2004. Mencari Sosok Desentralisasi Manajemen Pendidikan di Indonesia. Rineka Cipta, Jakarta.

Hamalik, Oemar 2006. Manajemen Pengembangan Kurikulum. Remaja Rosdakarya, Bandung.

Madrasah Aliyah Negeri (MAN) 3 Palembang 2007. Dokumentasi MAN 1 Bojonegoro. Tim Penyusun MAN 1 Bojonegoro. Tidak diterbitkan.

Merrill M. David dan David G.Twitchell 1994. Instructional Design Theory. Educational Technology Publications Englewood Cliffs, New Jersey.

Mondy, R.W dan Premeaux 1995. Management: Concepts, Practices and Skills. Prentice Hall Inc Englewood Cliffs, New Jersey.

Muhaimin 2005. Pengembangan Kurikulum Pendidikan Agama Islam di Sekolah, Madrasah dan Perguruan Tinggi. Rajawali Press, Jakarta.

Nasution, MN 2001. Manajemen Mutu Terpadu (Total Quality Management). Ghalia Indonesia, Jakarta. 


\section{2}

\section{JURNAL AL-AFKAR}

Vol. III, No. 2, Oktober 2015

Pidarta 1990. Perencanaan Pendidikan Partisipatori. Rineka Cipta, Jakarta.

Reigeluth, Charles M 1983. Instructional Design Theories and Model: An Overview of their Current Status. Lawence Erlbaum Associaties Publisher, London.

Romiszowski, A.J 1981. Designing Instructional Systems. Decision Making in Cource Planning and Curriculum Design. Kogan Page, New York.

Rosyada, Dede 2004. Paradigma Pendidikan Demokratis: Sebuah Model Pelibatan Masyarakat dalam Penyelenggaraan Pendidikan. Kencana, Jakarta.

Saptari, Nandang 2004. "Manajemen Pembelajaran Kelompok Belajar Usaha (KBU) Pusat Kegiatan Belajar Masyarakat (PKBM) bagi Peningkatan Pendapatan Warga Belajar Studi di PKBM Al-Ghazali Jamanis Tasikmalaya”, Tesis Universitas Pendidikan Indonesia (UPI) Bandung. tidak diterbitkan.

Sagala, Syaiful 2005. Konsep dan Makna Pembelajaran. Alfabeta, Bandung.

Santoso, Bambang 2005. "Kontribusi Kemampuan Manajemen

Kelas dan Kinerja Mengajar Guru terhadap Prestasi Belajar (Studi terhadap Guru SD Negeri di Lingkungan Kantor Dinas Pendidikan Kecamatan Sumedang Selatan Kabupaten Sumedang tahun 2004/2005)”, Tesis Universitas Indonesia. Tidak diterbitkan.

Shaleh, Abdul Rahman 2004. Madrasah dan Pendidikan Anak Bangsa: Visi, Misi dan Aksi. Rajawali Press, Jakarta.

Sudjana, Nana 1995. Penilaian Hasil Proses Belajar Mengajar. Remaja Rosdakarya, Bandung. 
Suparman, Atwi 1991. Desain Instructional. Proyek Pengembangan Pusat, Jakarta.

Suryabrata, Sumadi 1978. "Beberapa Prinsip Psikologi Belajar".

Teknologi Pembinaan Peserta Didik. Proyek Pembinaan Peserta

Didik, Direktorat Jenderal Pendidikan Tinggi, Departemen Pendidikan dan Kebudayaan.

Suryadi, Ace 1999. Pendidikan, Investasi SDM dan Pembangunan: Isu, Teori dan Aplikasi, Balai Pustaka, Jakarta.

Syafaruddin dan Irwan Nasution 2005. Manajemen Pembelajaran.

Quantum Teaching, Jakarta

2005. Manajemen Lembaga Pendidikan Islam. Ciputat Press, Jakarta.

Taufik, Ali Muhammad 2004. Praktik Manajemen Berbasis Al Qur'an. Gema Insani Press, Jakarta.

Terry, George R 2006. Prinsip-Prinsip Manajemen. Terjemahan J. Smith D. F. M. Bumi Aksara, Jakarta.

Winne, Philip H 1991. Motivation and Effective Teaching: Current Research. McChuchan, Berkeley.

Winkel, W.S 1991. Psikologi Pengajaran. Grasindo, Jakarta.

Wortman, Camille B., Elizabeth F. Loftus and Mary E.Marshall 1985. Psychology. Alfred A. Knopt. Inc, New York. 